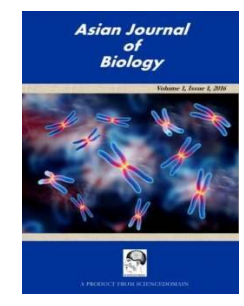

\title{
Bio-insecticidal and Grain Protectant Activities of Mixed Powder of Ocimum gratissimum and Vernonia amydalina against Callosobruchus maculatus (Coleoptera: Bruchidae) in Calabar, Nigeria
}

\author{
A. I. $\mathrm{Nta}^{1}$, B. E. Agbo ${ }^{2}$ and N. S. Udoekong ${ }^{3}$ \\ ${ }^{1}$ Department of Zoology and Environmental Biology, University of Calabar, Calabar, Nigeria. \\ ${ }^{2}$ Department of Microbiology, University of Calabar, Calabar, Nigeria. \\ ${ }^{3}$ Department of Science and Technology, Akwa Ibom State Polytechnic, Ikot Osurua, Ikot Ekpene, \\ Akwa Ibom State, Nigeria.
}

Authors' contributions

The work was carried out in collaboration between all authors. Author AIN designed the study, performed the statistical analysis, wrote the protocol and wrote the first draft of the manuscript. Authors BEA and NSU managed the analyses of the study. Author BEA managed the literature searches. All authors read and approved the final manuscript.

\begin{abstract}
Article Information
DOI: $10.9734 / \mathrm{AJOB} / 2017 / 33500$

(1) Xing Li, Division of Biomedical Statistics and Informatics, Department of Health Sciences Research, Mayo Clinic College of Medicine, USA

Reviewers:

(1) Shravan M Haldhar, Central Institute for Arid Horticulture, Bikaner, India. (2) Adriana Neske, Universidad Nacional de Tucuman, Argentina. Complete Peer review History: http://www.sciencedomain.org/review-history/19070
\end{abstract}

Original Research Article

Received $18^{\text {th }}$ April 2017

Accepted $8^{\text {th }}$ May 2017

Published $15^{\text {th }}$ May 2017

\begin{abstract}
The bio-insecticidal and grain protectant activities of mixed powder of Ocimum gratissimum and Vernonia amygdalina upon Callosobruchus maculatus was carried out in Calabar, Nigeria during the dry season (August to November) of 2015. The mortality rate of cowpea weevil treated $V$. amygdalina: $O$. gratissimum at 100: 0 concentrations were $17.0 \%, 27.0 \%$, and $47.0 \%$ for a period of $24 \mathrm{hrs}, 48 \mathrm{hrs}$ and $72 \mathrm{hrs}$, respectively. Concentrations 0:100 gave a percentage mortality of $47.0 \%$, $67.0 \%$ and $73.0 \%$ at $24 \mathrm{hrs}, 48 \mathrm{hrs}$ and $72 \mathrm{hrs}$, respectively. $80: 20$ and 20: 80 concentrations gave $33.3 \%$ and $47.0 \%$ at $24 \mathrm{hrs}$ and $48 \mathrm{hrs}$, but $80: 20$ gave $47.0 \%$ while $20: 80$ gave $57.0 \%$ mortality rate at $72 \mathrm{hrs}$. 50: 50 concentrations gave $73.0 \%, 77.0 \%$, and $80.0 \%$ mortality rate at $24 \mathrm{hrs}$, $48 \mathrm{hrs}$ and
\end{abstract}

${ }^{*}$ Corresponding author: E-mail: beagbo@unical.edu.ng, profbaseadeone@gmail.com; 
$72 \mathrm{hrs}$, respectively. The 0 : 0 concentrations gave $0.0 \%, 3.3 \%$, and $7.0 \%$ mortality rate at $24 \mathrm{hrs}$, $48 \mathrm{hrs}$ and $72 \mathrm{hrs}$, respectively. The effect on the oviposition of cowpea weevil revealed that the mean value of eggs laid on seeds were 5.0, 2.3, 3.3, 2.8, 1.0 and 7.0 for 100:0; 0:100; 80:20; 20:80; 50:50 and 0:0 concentrations, respectively. The effects of mixture of $V$. amygdalina: $O$. gratissimum powder on the emergence of cowpea weevil gave a mean value of adult weevil emergence as 5.3, 3.0, 5.0, 3.3, 1.3 and 8.0 for 100:0, 0:100, 80:20, 20:80, 50:50 and 0:0 concentrations respectively. Mixed powder of $V$. amygdalina: $O$. grattisimun with $50: 50 \%$ concentrations conferred the highest bio-insecticidal potency against $C$. macullatus during the experimental investigation. This was evident from the fact that treatment with $V$. amygdalina: $O$. grattisimum (50:50\%) concentration attained $80.0 \%$ mortality at $72 \mathrm{hrs}$ of exposure, which was followed by $V$. amygdalina: $O$. grattisimum (0: $100 \%$ ) concentration with $73.0 \%$ mortality.

Keywords: Bio-insecticidal; oviposition; Vernonia amygdalina; Ocimum gratissimum; ovicidal; Callosobruchus maculates.

\section{INTRODUCTION}

Cowpea is a legume crop that can be grown prosperously in extreme environment like high temperature, low rain and impoverished soil with little input $[1,2]$. Cowpea (plant) can be utilized at all stage of growth as vegetable crops, the delicate green leaves are useful food source in Africa and are prepared as a pot herb-like spinach $[1,3]$. The dry and mature seed are good for boiling and canning and food for livestock $[4,5]$. The nutrient content of mature cowpea include: carbohydrate $63.6 \%$, Protein $24.8 \%$, fibre $6.3 \%$, fat $1.9 \%$, thiamine $0.00074 \%$, Riboflavin $0.00042 \%$ and Niacin $0.00281 \%$ they are rich in lysine, tryptophan and amino acid [6]. Cowpea ( $V$. unguiculate) is an important diet protein in Africa where Callosobruchus maculatus has become a major storage pest of the seed. Cowpea is prone to pest infestation, during pod, dry seed stage in the field and in storage [7]. Infestation was often less serious problem because farmers' cultivated traditional varieties which though low yield were generally more resistant to attack by pest $[1,5]$. However, the introduction of high yielding pulse varieties has results in high storage losses since they are usually more susceptible to pest damage, the pesticide properties of many plants have been known for a long time and natural pesticide based on plant extracts such as Rotenone, Nicotine and Pyrethrum have been routinely used in pest control during the earlier half of the century $[1,4,7]$. After the World War II, plant extract based pesticide loss their importance with the production of synthetic organic chemicals, which were concentrated product with a high knock down effect on pest organism [1,7]. The use of these organo-chlorine and organophosphorus compound however has led to the unhealthy effect on environment and human beings [1,5]. Bio-pesticides of plant origin have been found to have wide spectrum insecticidal properties with reduced persistence and toxicity in relation to organo-chlorine and organophosphorus compound $[1,7,8]$. They are easily available, can be produced within farmer's vicinity providing a more sustainable approach to pest $[1,8,9]$.

Pesticide plants are utilized in two main ways: for the active compound is isolated, identified and chemically synthesized. If feasible, these compounds are synthesized and marketed by the industries producing them. The second method which is suitable for farmers in developing countries involves the use of plant substances or products which are obtained and used directly. These practices are labour intensive, but are often economically sound and do not require sophisticated technology $[5,10,11]$.

According to Nisbet et al. [12], ground plant parts and their extracts suppress fecundity and fertility of many insects. Researchers have reported that plant parts or extracts mixed with grains reduces insect oviposition, egg hatchability, post embryonic development and progeny production. According to Boeke et al. [13], plant derivatives also reduce the survival rates of larvae, pupal and adult emergence. Plant extracts, powders and essential oil from different bioactive plants were reported as repellant against different economically important stored products insects [14].

Some plant substances employed as protectantpoo on stored cowpea grain attacked by Callosobruchus maculatus include Vernonia Amyglalina (Bitter leaf) and Ocimum gratissimum (scent leaf). Botanically, they can be used as plant substance (either powder or extract) to control pest in stored products and in the field. The leaves composite include lactone, oxalic 
acid, hydrocyanic acid (HCN) is reported to be active principal extractable non-quantitatively by different solvent, while the hydrocyanic acid is very volatile $[14,15]$.

Ocimum gratissiumum (scent leaf) have a wide use throughout West Africa as febrifuge, antimalaria and anti-convulsant. The crushed leaf juice is of great help in the treatment of convulsion; stomach pain and catarrh, oil from the leaves has been found to possess antiseptic, anti-bacterial and anti-fungal activities [16]. It is used as spices in terms of the flavour, it is a source of income, it may also be used as plant substance (either powder or extracts) to control pest of stored product [17].

\section{MATERIALS AND METHODS}

\subsection{Collection of Plant Materials}

Fresh mature leaves of Vernonia amygdalina and Ocimum gratissimum were collected from the botanical garden in University of Calabar in Calabar Municipality, Nigeria $\left(5^{\circ} 45^{1} \mathrm{~N}\right.$ and $\left.8^{\circ} 30^{1} \mathrm{E}\right)$. The collected plants were taken in sterile bags to the herbarium unit in Botany department where their identities were confirmed.

\subsection{Preparation of Plants Powders}

The collected test plants leaves were separately air-dried on a well-ventilated laboratory bench in Zoology and Environmental Biology department at temperature of $30 \pm 2^{\circ} \mathrm{C}$ and relative humidity of $76 \pm 5 \%$ for 14 days. The crisp dried plant materials were separately milled in an electric miller (super-master model SMB 2977, Japan), and the obtained powders were separately sieved through a $0.5 \mathrm{~mm}$ mesh net to have fine homogenous powder. The leaf powders of the test plants ( $V$. amygdalina and $O$. gratissimum) were compounded in the ratios of 100:0, 0:100, $80: 20, \quad 20: 80$ and 50:50 respectively. Each compounded powder which was stored in labelled air-tight container and kept at ambient laboratory condition ns was used for assessment within 48 hours.

\subsection{Collection and Preparation of Cowpea Seeds}

The black eyed variety of cowpea seeds were purchased from a local market (lka lka Oqua market) in Calabar, Cross River state, Nigeria. The seeds were taken to the laboratory where they were carefully inspected with hand lens and infested seeds (seeds having one or more feeding holes) were removed. The un-infested seeds were sterilized by storing in deep freezer (Thermocool model 750) at temperature of minus $15^{\circ} \mathrm{C}$ for 48 hours. Twelve (12) hours before application of treatment, the sterilized seeds were removed and air-dried on laboratory bench for acclimatization.

\subsection{Experimental Procedure}

Fifty (50) grams of sterile cowpea seeds were weighed separately into eighteen (18) plastic transparent containers (15 $\mathrm{cm}$ in diameter). The set-up was treated in a completely randomized designed with $5 \%(\mathrm{w} / \mathrm{w})$ of the different combinations of $V$. amygalina and $O$. gratissimum. An untreated 50 grams of cowpea seeds was used as control.

Four pairs of freshly emerged (age $=0-24 \mathrm{hr}$ ) adult $C$. maculatu (4 males and 4 females) were taken from a cultured stock and introduced into each container, covered with 0.53 mesh net to enhance aeration and exclude escape of insects. The Vernonia amygdalina and Ocimum gratissimum powder of varying proportion were then introduced. Each treatment was replicated thrice.

\subsection{Data Collection}

Adult mortality count was carried out at 24,48 , 72 and 96 hours after treatment. At each count, the number of dead weevils was noted, the dead weevils were carefully removed and discarded while the live ones were allowed to continue the experiment. Insects were confirmed dead if it did not move when torch with entomological pin. At 60 days post treatment, all insects (dead and alive) were removed from the experimental containers using a pair of forceps.

From the data collected, percentage of mortality, were calculated using the formulae

$$
\% \text { mortality }=\frac{\text { number of dead weevils }}{\text { Total number of weevils }} \times \frac{100}{1}
$$

\subsection{Anti-oviposition Test}

At seven (7) days post treatments, all weevils (dead and alive) were removed from each experimental set-up/ container. Twenty seeds were randomly selected and taken from each experimental unit and examined using hand lens, number of eggs laid as they were counted. This count data gave the anti-oviposition index of the respective treatment. 
Table 1. Treatment of Vernonia amygdalina and Ocimum gratissium

\begin{tabular}{ll}
\hline Plant leaf & Treatments \\
\hline $\mathrm{Va}_{100}: \mathrm{Og}_{0}$ & Verninia amyygdalina $100 \mathrm{~g}+$ Ocimum gratissimum $0 \mathrm{~g}$ \\
$\mathrm{Va}_{0}: \mathrm{Og}_{100}$ & V. amygdalina $0 \mathrm{~g}+$ O. gratissimum $100 \mathrm{~g}$ \\
$\mathrm{Va}_{80}: \mathrm{Og}_{20}$ & V. amygdalina $80 \mathrm{~g}+$ O. gratissimum $20 \mathrm{~g}$ \\
$\mathrm{Va}_{20}: \mathrm{Og}_{80}$ & V. amygdalina $20 \mathrm{~g}+$ O. gratissimum $80 \mathrm{~g}$ \\
$\mathrm{Va}_{50}: \mathrm{Og}_{50}$ & V. amygdalina $50 \mathrm{~g}+$ O. gratissimum $50 \mathrm{~g}$ \\
$\mathrm{Va}_{0}: \mathrm{Og}_{0}$ & Control \\
\hline
\end{tabular}

\subsection{Adult Emergence Test}

Thirty one (31) days after completing the mortality test the number of adult $C$. maculatus emerging from each treatment group were counted. This count data which was taken for seven days gave the reproductive potential inhibition/ adult cumulative emergence index.

\subsection{Data Analysis}

All data collected from respective study parameter were subjected to one way analysis of variance, means were separated using LSD (least significant difference) and conclusion drawn at $95 \%$ confidence limit.

\section{RESULTS}

At 96 hours post-treatment, the highest cumulative percentage of mortality $(85 \%)$ of $C$. maculatus was obtained in compounded $V$. amygdalina and $O$. gratissimum in the ratio 50:50. This was closely followed $76 \%$ obtained from $V$. amygdalina: $O$. gratissimum in the ratio $0: 100$. These two treatments had similar effect and significantly different $(P<0.5)$ mortality than all other treatment groups. $V a 20 \mathrm{~g}+\mathrm{Og} 80 \mathrm{~g}$ treatment gave $62 \%$ cumulative percentage mortality while the control had the least $(7.00 \%)$. The above information is presented in Table 2.

\subsection{Anti Oviposition}

At seven days after treatment the highest number of eggs laid were recorded in the untreated control (8.3) and this was significantly different $(P<0.05)$ from the number laid in all other treatment groups. The least number of eggs (1.20) were observed in mixed Va 50: Og 50 treatment group. $V$. amygdalina and $O$. gratissimum treatments in the combination ratios of 20:80 and $0: 100$ had similar effects of (2.8 and 2.3, respectively on oviposition). This was followed by comparable mean egg oviposition of 4.0 and 3.6 in $V$. amygdalina and $O$. gratissimum Va80:Og20 and Va100: Og 0 combination, respectively. The above information is as presented in Table 3.

\subsection{Adult Emergence / Reproduction Inhibition}

The different combinations of test plant leaf powders (50:50, 80:20, 20:80, 100:0 and 0:100), showed significant effect on reproduction and

Table 2. The effect of $V$. amygdalina and/or $O$. gratissimum powder(s) on mortality of Callosobruchus maculatus adult

\begin{tabular}{|c|c|c|c|c|c|}
\hline Treatment & Combination (g) & & $\% \mathrm{Mo}$ & rtality & \\
\hline Leaf powders & & $24 \mathrm{hrs}$ & 48 hrs & $72 \mathrm{hrs}$ & $96 \mathrm{hrs}$ \\
\hline V. amygdalina : O. gratissimum & Vam $100 \mathrm{~g} \pm$ Ogr $0 \mathrm{~g}$ & $17.0 \pm 2.0$ & $27.0 \pm 3.6$ & $47.0 \pm 4.4$ & $51.0 \pm 1.7$ \\
\hline V. amygdalina : O. gratissimum & Vam $0 \mathrm{~g} \pm$ Ogr $100 \mathrm{~g}$ & $42.0 \pm 3.2$ & $64.0 \pm 1.0$ & $73.0 \pm 2.0$ & $76.0 \pm 2.0$ \\
\hline V. amygdalina : O. gratissimum & Vam $80 \mathrm{~g} \pm$ Ogr $20 \mathrm{~g}$ & $31.3 \pm 0.6$ & $47.0 \pm 4.4$ & $48.0 \pm 1.0$ & $50.0 \pm 1.0$ \\
\hline V. amygdalina : O. gratissimum & Vam $20 \mathrm{~g} \pm$ Ogr $80 \mathrm{~g}$ & $34.0 \pm 1.0$ & $47.0 \pm 4.4$ & $57.0 \pm 2.0$ & $62.0 \pm 1.0$ \\
\hline V. amygdalina : O. gratissimum & Vam $50 \mathrm{~g} \pm$ Ogr $50 \mathrm{~g}$ & $75.0 \pm 2.6$ & $77.0 \pm 1.0$ & $80.0 \pm 1.2$ & $86.0 \pm 4.0$ \\
\hline $\begin{array}{l}\text { Control (V. amygdalina: } \\
\text { O. gratissimum) }\end{array}$ & Vam $0 \mathrm{~g} \pm$ Ogr $0 \mathrm{~g}$ & $0.0 \pm 0.0$ & $3.3 \pm 0.6$ & $7.0 \pm 0.6$ & $8.0 \pm 2.0$ \\
\hline
\end{tabular}


adult emergence when compared with the control. The highest percentage inhibition of reproduction and the lowest number percentage of emerged adults were recorded in Va50:Og50 treatment i.e. the treatment with equal proportion of test plant powders while the control showed the least reproductive inhibition capacity but highest percentage of emerged adult (78.50). Va80:Og20 and Va20:Og80 respectively gave 45.75 and $40.25 \%$ of emerged adults. The percentage of adult emerging from Va100:Og0 and $\mathrm{VaO}$ and $\mathrm{Og} 100$ treatment group was $39.00 \%$ and $54.25 \%$ respectively (Table 4 ).

Table 3. Effect of $V$. amygdalina and $O$. gratissimum combination on oviposition rate of adult $C$. maculatus

\begin{tabular}{lll}
\hline Treatment & $\begin{array}{l}\text { Number of } \\
\text { seeds }\end{array}$ & $\begin{array}{l}\text { Mean } \\
\text { number of } \\
\text { eggs laid }\end{array}$ \\
\hline Va100:Og0 & 20 & $4.00 \pm 1.00$ \\
Va0:Og100 & 20 & $2.30 \pm 0.57$ \\
Vago:Og20 & 20 & $3.60 \pm 0.57$ \\
Va20:Og80 & 20 & $2.80 \pm 0.57$ \\
Va50:Og50 & 20 & $1.20 \pm 0.57$ \\
Va0:Og0 & 20 & $8.30 \pm 0.57$ \\
\hline
\end{tabular}

Table 4. Effect of mixed leaf powder of $V$. amygdalina and 0 . gratissimum treatment on adult $C$. maculatus emergence

\begin{tabular}{ll}
\hline Treatment & $\begin{array}{l}\text { Adult emergence } \\
\%\end{array}$ \\
\hline Vag100:Og0 & $54.25 \pm 0.57$ \\
Va0:Og100 & $39.00 \pm 2.65$ \\
Va80:Og20 & $45.75 \pm 0.57$ \\
Va20:Og80 & $40.25 \pm 0.57$ \\
Va50:Og50 & $35.50 \pm 0.57$ \\
Va0:Og0 & $78.50 \pm 0.57$ \\
\hline
\end{tabular}

\section{DISCUSSION}

Table 2 presents the result of $V$. amygdalina and/or $O$. gratissimum powders on mortality rate of Callosobruchus maculatus adult at different duration. Va50:Og50 gave $86 \%$ - the highest percentage mortality at 96 hours duration followed by $\mathrm{Va0}: \operatorname{Og} 100$ which gave $76 \%$ mortality at 96 hours duration. This means that the longer the duration of powder application, the greater the effect on the insect. The findings from this research is in agreement with an earlier research carried out by Musa et al. [5]. The significantly higher mortality obtained in 50:50 and 0:100 combinations of $V$. amygdalina and $O$. gratissimum was probably due to the pungent odour of $O$. gratissimum. This confirms reports by Kouninki et al. [18] that leaves of aromatic plants are toxic to beetles and weevils attacking, storage production. Secondly the combinations of two aromatic plant in equal proportion may have increased the insecticidal potency thus resulting in higher mortality [19] reduced oviposition and inhibition of development and subsequent adult emergence Emeazor et al. [20].

Table 3 presents the result of effects of $\mathrm{V}$. amygdalina and $O$. gratissimum combination on ovoposition rate of adult C. maculatus. Va50:Og50 combination gave the best result with an average number of eggs laid to be 1.20. The said treatment (Va50:Og50) reduced the average number of laid eggs from 8.30 to 1.20 , which is a nice result. Significantly reduction in oviposition, observed in the various combination of test plant when compared with control also indicate that the pungent odour may have affected the behavior of $C$. maculatus through the smell sensilla present in their antennal. This odour probably created a vapour barrier preventing the weevils from contacting the cowpea and ovipositing on them $[1,5,7,21]$.

From the Table 4, it can be seen that Va50:Og50 gave the least percentage adult emergence. This concentration gave an excellent result as compare to the control treatment which gave $78.50 \%$ of adult emergence. Results obtained from the biological assays indicated that leaf powders of $V$. amygdalina, $O$. gratissimum and the different combinations of the leaf powders of plants had varying insecticidal potency against $C$. maculatus. When compared with the control, all plant material were effective in increasing insect mortality and reducing oviposition, development and adult emergence thus reducing the overall population of $C$. maculatus at 31 days after treatment.

The combinations of the plant powders may have also increased toxicity to the immatured stages and adult of $C$. macvulatus $[19,22]$. The reduced oviposition, suppression of development and subsequent reduction in adult emergence confirms the reports of $[9,23]$. Lale [24] said that powders of medicinal plants when applied alone or in combination are effective in controlling insect pest of stored agricultural produces. The powders may have blocked the spiracles and other respiratory structures of the insects thereby suffocating and death. 


\section{CONCLUSION}

The results showed that $50: 50$ and $0: 100$ ratio compounded $V$. amygalina and $O$. gratissimum had $85 \%$ and $76 \%$ effect on the insects. The two treatments had similar effect with a significant difference at $\mathrm{P}<0.5$ mortality. The highest percentage inhibition of reproduction/adult emergence was recorded at Va50:Og50 treatment. When compared with the control, all plant material were effective in increasing insect mortality and reducing oviposition, development and adult emergence thus reducing the overall population of $C$. maculatus at 31 days after treatment. The potency of the combined concentrations of $V$. amygdalina: $O$. gratissimum (50:50\%) of these plant substances was due to the odour they produce, which may have exerted a toxic effect by disrupting normal respiratory activities of the cowpea weevil, thereby resulting in asphyxiation and subsequent dead; it may also have acted as contact poison on the weevil. It equally may have ovicidal and larvacidal properties. It is recommended that similar studies be conducted using separately other parts of the test plant like the stem and bark of $V$. amygdalina and $O$. gratissimum to further evaluate their bio-insecticidal potency against stored grain pests.

\section{COMPETING INTERESTS}

Authors have declared that no competing interests exist.

\section{REFERENCES}

1. Shazia OWM, Reuben MM, Makundi R, Misangu RN, Kilonzo B, Mwatawala M, Lyimo HF, Ishengoma CG, Dastun GM, Mulungu LS. Control of cowpea weevil (Callosobruchus maculatus L.) in stored Cowpea (Vigna unguiculatus L.) grains using botanicals. Asian Journal of Plant Sciences. 2006;5(1):91-97.

2. Hu RD, Khan G, Dedeh BD. Selection of piper cultivar for the control of bruchid Callosobruchus maculatus (F) on stored cowpea (Vigna unguiculata (L) walp seeds. Journal of Applied Entomology. 2008; 23(2):234-237.

3. Arong GA, Usua EJ. Comparative development of cowpea bruchid (Callosobruchus maculates) on pod seed of some cowpea cultivars; 2006.
4. Adedire CO, Akinneye JO. Biological activity of tree marigold, Tithonia diversifolia on cowpea seed bruchid, Callosobruchus maculatus (Coleoptera: Bruchidae). Annals of Applied Biology. 2004;144:185-189.

5. Musa AK, Oyerinde AA, Owolabi FO. Evaluation of the efficacy of mixed leaf powder of Vernonia amygdalina and $O$. gratissimum against Callosobruchus maculates. Academic Journal of Entomology. 2009;2(2):85-87.

6. Gómez C. COWPEA: Post-Harvest Operations. Food and Agriculture Organization of the United Nations (FAO), Rome, Italy; 2004.

7. Agbo BE, Nta Al, Ajaba MO. A Review on the Use of Neem (Azadirachta indica) as a Bio-pesticide. Journal of Bio-pesticide and Environment. 2015;2(1):58-65.

8. Rao AP, Agbo BE, Udoekong NS, Etuk, $\mathrm{HA}$. Biological control of the plant pathogen: Aspergillus niger. Journal of Biopesticide and Environment. 2017. In press.

9. Mordue AJ, Morgan ED, Nisbet AJ. Azadirachtin, a natural product in insect control. In: Gilbert LI, latrou K, Gill SS. (Eds.). Comprehensive Molecular Science. Elsevier, Oxford. 2005;117-135.

10. Singh DK. Biodegradation and bioremediation of pesticide in soil: Concept, method and recent developments. Indian Journal of Microbiology. 2008;48:35-40.

11. Aislabie J, Foght J, Saul D. Aromatic hydrocarbon-degrading bacteria from soil near Scott base. Antarctica, Polar Biology. 2000;23:83-188.

12. Nisbet AJ, Woodford JAT, Strang RHC. The effects of azadirachtin-treated diets on the feeding behaviour and fecundity of the peach-potato aphid, Myzus persicae. Entomological Experimental and Applied Journal. 1994;71:65-72.

13. Boeke S, Baumgart I, Kassou D. Toxicity and repellency of African plant traditionally used for the protection of stored cowpea against Callosobruchus maculatus. Journal of Stored Product Res. 2004;40(4):423-38.

14. Law-ogbomo KE, Enobakhare DA. The use of leaf powders of Ocimum gratissium and Vernonia amygdalina for the management of Sitophilus orgzae (Lin) in stored Rice. Journal of Entomology. 2007;4:253-257.

15. Nelson S, William M. Agricultural applications in green chemistry. American Chemical Society, Washington D.C.; 2004. 
16. Hashmat I, Azad $\mathrm{H}$, Ahmed A. Neem (Azadirachta indica $A$ Juss)-A native drug store: An overview. International Research Journal of Boil Science. 2012;1:76-79.

17. Larrauri JA, Goñi I, Martín-Carrón N, Rupérez P, Saura-Calixto F. Measurement of health- promoting properties in fruits dietary fibres: Antioxidant capacity, fermentability and glucose retardation index. J. Sci. Food Agric. 1996;71:515-9.

18. Kouninki $H$, Haubruger $E$, Noudjou FC, Lognnory G, Mallaisse F, Ngassoum MB, Goudoum A, Mapongmetsem PM, Ngamo LS, Hance T. Toxicity of some terpenoids of essential oils of Xylopia aethiopica from Cameroon against Sitophilus zeamais Motschulsky. Journal of Applied Entomology. 2007;13(4):269-274.

19. Ofuya TI. Oviposition deterrence and ovidal properties of some plant powders against Callosobruchus maculatus in stored cowpea (Virna unginiculata) seeds. Journal of Agricultural Science. 1990;115: 343-345.

20. Emeazor KC, Emosuirue SO, Ogbuji RO. Preliminary evaluation of the efficacy of mixed seeds powders of Piper guineese
(Schum and Thorn) and Thevelia peruviana (Person) against Calloxobruchus maculatus (F.) Colereptera Bruchidac. Nigerian Journal of Entomology. 2007;24:114-118.

21. Khanam L, Talukder D, Khan A. Insecticidal property of Indigenous plants against Tribolium confusum duval. Bangladesh Journal. 1990;18(2).

22. Omotoso OT. Evaluation of some plant powders as toxicants and anti feedants in the control of maize damage by the maize weevil Sitophilles zeamais Motschulsky in storage. Tlltre Scientist of Physical Sciences. 2004;16(2):221-130.

23. Islam MT, Castle SJ, Ren S. Compatibility of the insect pathogenic fungus Beauveria bassiana with Neem against sweetpotato whitefly, Bemisia tabaci, on eggplant. Entomologia Experimentalis et Applicata. 2010;134:28-34.

24. Lale NES. An overview of the use of plant products in the management of stored product colereptera in the tropics. Pest Harvest News and Information. 1995;6: $69 N-78 N$.

(c) 2017 Nta et al.; This is an Open Access article distributed under the terms of the Creative Commons Attribution License (http://creativecommons.org/licenses/by/4.0), which permits unrestricted use, distribution, and reproduction in any medium, provided the original work is properly cited.

Peer-review history:

The peer review history for this paper can be accessed here: http://sciencedomain.org/review-history/19070 